\title{
PREKMURSKE LJUDSKE PESMI \\ V GLASOSLOVNI RAZPRAVI AVGUSTA PAVLA (1909)
}

\section{TJAŠA JAKOP}

Vprispevku osvetliujemo narečno podobo izbranih prekmurskih ljudskih pesmi. Jezik ljudskih pesmi navadno ni pravo narečje, je vmesna stopnja med narečjem in knjižnim jezikom (t. i. nadnarečje). Narečnosti se najbolj približajo zapisi ljudskih pesmi v fonetični pisavi. Včlanku bomo analizirali nekaj prekmurskih narečnih pesmi, objavljenih leta 1909 $v$ glasoslovni razpravi Avgusta Pavla, in jih primerjali z zapisi v nadnarečni podobi.

Ključne besede: slovenska ljudska pesem, dialektologija, narečno vs. nadnarečno pogovorno, panonska narečna skupina, prekmursko narečje, Avgust Pavel
In this article we shed light on the dialectal picture of selected Slovenian folk songs. The language of folk songs is usually not a proper dialect, but an intermediate stage between dialect and written language (in most cases it is a supra-dialect). Folk songs in phonetic writing come closest to the original dialect image of a folk song. In this article we will analyse some dialect folk songs from the Prekmurje region in the phonetic transcription recorded by a linguist August Pavel (published in 1909); these will later be compared with the same folk songs in supra-dialectal form.

Keywords: Slovenian folksongs, dialectology, standardisation, Pannonian dialect group, Prekmurje dialect, Avgust Pavel.

\section{UVOD}

Jezik ljudskih pesmi ni čisto narečje, je vmesna stopnja med narečjem in knjižnim jezikom (Kumer, 1975: 69; Golež Kaučič, 2003, 2018; Jakop, 2006; Stanonik, 2008), torej t. i. nadnarečje. Za jezik v ljudski pesmi je namreč značilno, da ne gre za narečje, saj že njena metrična pravila določajo nad običajno govorico privzdignjen pesniški jezik (Merhar, 1961: 146; Kumer, 1975: 69), zato govorimo o narečnih sestavinah, v katerih prepoznavamo t. i. pokrajinskost jezika (Jakop, 2006: 68), od koder pesem izvira. Narečne značilnosti so najdosledneje ohranjene v ljudskih pesmih, ki so zapisane v fonetični pisavi. V članku bomo analizirali nekaj prekmurskih narečnih pesmi, objavljenih leta 1909 v glasoslovni razpravi Avgusta Pavla. ${ }^{1}$ Primerjali jih bomo z analizami poznejših zapisov. Ti fonetični zapisi nam omogočajo natančen slušni vtis lokalnega narečja oz. govora, ki se v podrobnostih loči od sosednjih prekmurskih, še bolj pa od bolj oddaljenih panonskih in štajerskih različic.

\section{POKRAJINSKE RAZLIČICE LJUDSKIH PESMI}

Pri preučevnju besedil slovenskih ljudskih pesmi odkrijemo jezikovne različice z opaznim prehajanjem iz krajevnega narečnega $v$ nadnarečni in mestoma celo popolnoma knjižni

1 Avtorica je del Pavlove razprave prevedla iz madžarščine v slovenščino. 
jezik. Razlog za odsotnost lokalnih narečnih prvin pa je tudi "potovanje« pesmi po širšem območju od narečnega v smeri nadnarečnega (Jakop, 2006: 52). Narečno podobo pesmi lahko spremeni že sam prehod iz ustnega v pisni kod, saj gre pri (nefonetičnem) zapisovanju nehote za določeno mero posploševanja, abstrahiranja in poknjiževanja (n. d.: 54).

$[\mathrm{P}]$ rav narečja so del lokalne in tudi vsesplošne kulture. Ljudske pesmi bi lahko bralcem neprisiljeno pokazale razčlenjenost slovenskega jezika in utrjevale dejstvo, da so ljudske pesmi v svojem bistvu narečne. Tudi še tako slavistično naravnan koncept folkloristike tega ne bi smel spregledati, kaj šele opustiti, saj je s tem odstranjena ena od temeljnih značilnosti ustnega slovstva. (Terseglav, 2004: 34)

Prispevek predstavlja rezultat opravljenih dialektoloških analiz ljudskih pesmi s skrajnega severovzhodnega dela slovenskega jezikovnega ozemlja. Namen prispevka je

1. prikazati razliko med ohranjenostjo narečnosti ljudskih pesmi v dialektološkem delu Avgusta Pavla v primerjavi z nekoliko fonetično posplošenim zapisovanjem v nekaterih zbirkah ljudskih pesmi (npr. Štrekelj, 1904-1907; Dravec, 1957) in

2. opazovati stopnjo ohranjenosti narečnih oz. nadnarečnih (regionalnih) elementov na posamičnih jezikovnih ravninah (leksika, sintaksa, fonologija in morfologija). ${ }^{2} \mathrm{Hkrati} s$ skladnjo se poknjiževanje najprej dotakne glasoslovja; manj se spreminja besedje (leksika), najmanj pa oblikoslovje.

\section{PREKMURSKI KNJIŽNI JEZIK}

Med Slovenci na Ogrskem, ki so v avstrijskih deželah živeli upravno, politično in kulturno ločeni od Slovencev, se je uporabljal in razvijal poseben slovenski knjižni jezik (t. i. prekmurski knjižni jezik), ki je v obdobju od 18. do prve polovice 19. stoletja dosegel že dokaj ustaljeno obliko. Knjižna prekmurščina je bila nadnarečna tvorba, nastala na podlagi ravenskih in goričkih značilnosti, in se je v Prekmurju uporabljala od prve knjige v prekmurščini. Evangeličanski duhovnik Franc Temlin je leta 1715 prevedel Luthrov Mali katekizem v slovenščino), za potrebe protestantov pa jo je normiral Štefan Küzmič s prevodom Nove zaveze (Nouvi zákon) leta 1771. Prekmurski knjižni jezik se je uporabljal vsaj do leta 1919, ko se je Prekmurje združilo s preostalo Slovenijo v skupni državi, v nekaterih jezikovnih položajih (npr. pri evangeličanskem bogoslužju) pa se je ohranilo tudi pozneje.

2 Po drugi strani pa dialektološki zapisi večinoma ne upoštevajo melodije, ki vpliva na prehod iz narečnosti v nadnarečnost. Narečnost govorjenega jezika se namreč razlikuje od narečnosti oziroma nadnarečnosti petja, saj je ena od najpomembnejših značilnosti ljudske pesmi ta, da se poje. 


\section{PREKMURSKO NAREČJE}

Prekmurje je ozemlje med Muro in mursko-rabskim razvodjem na skrajnem severovzhodu Slovenije. Je del naravno in gospodarsko zaokroženega Pomurja in obsega pretežni del Goričkega, jugozahodno tretjino Lendavskih goric ter ravnino na levi strani Mure: Dólinsko in Ravénsko. Pokrajina na levem bregu reke Mure je torej geografsko razdeljena na tri dele: severni (Goričko), osrednji (Ravensko) in južni (Dolinsko).

Prekmursko narečje je del panonske narečne skupine. Govorijo ga na območju levega brega Mure, vključno s Porabjem na Madžarskem in Radgonskim kotom v Avstriji. Prekmursko narečje sestavljajo tri različice: goričko, ravénsko in dólinsko, ki se med seboj razlikujejo $\mathrm{v}$ mlajših inovacijah v glasoslovju, npr. v izgovoru kratkega in dolgega $a$ ali zvočnika $j$ (tega ohranja le dólinsko, drugod pa ima položajne variante $d j, g$ ali $d \check{z}$ ).

Po definiciji Tineta Logarja (1975: 115) se prekmursko narečje govori v Prekmurju, ob zgornji Rabi v okolici Monoštra na Madžarskem in v nekaj vaseh ob madžarsko-avstrijski meji v Avstriji. ${ }^{3}$ Narečje pozna samo jakostno (tj. netonemsko) naglaševanje, ima pa kolikostno nasprotje: dolgi in kratki samoglasniki so možni v vseh besednih zlogih. Prav ta lastnost ga bistveno loči od drugih slovenskih narečij, ki dovoljujejo kratko naglašene samoglasnike samo v zadnjih ali edinih besednih zlogih. Sistem dolgih samoglasnikov je monoftongično-diftongičen.

Vilko Novak (1936: 5) je razdelil prekmursko narečje na tri govore: južnega govorijo Dolinci od Murske Sobote do Lendave, med Muro in Lendavo; srednjega govore Ravenci od Murske Sobote proti Cankovi; severnega ali goričkega pa Goričanci. Na tri podnarečja, severno, osrednje in južno, je prekmurččino razčlenila tudi Zinka Zorko (1994: 232): severno podnarečje se govori ob zgornji Ledavi in v Slovenskem Porabju, osrednje od Cankove prek Murske Sobote do Filovcev in Kobilja, južno, tj. dolinsko, pa vzdolž Mure.

Gorička različica se torej govori severno od Cankove in v Porabju, ravensko narečje od Cankove (ob meji z Avstrijo) proti vzhodu in južno od Murske Sobote do Rakičana, dolinsko pa južno od Rakičana (oz. Murske Sobote) do reke Mure in ob Ledavi. Ločnice med temi področji so se izoblikovale zaradi naravnih ter politično- in cerkvenoupravnih dejavnikov, mejo med severnim in osrednjim delom pa je izoblikoval naravni relief goričkega gričevja. Severni del je imel središče v Monoštru in Gornji Lendavi (današnji Grad), osrednji v Murski Soboti, južni pa v Turnišču in Dolnji Lendavi (današnja Lendava). V zamejstvu na Madžarskem se govori t. i. porabska različica, ki zajame krajevne govore vse do Monoštra. ${ }^{4}$

Avgust Pavel (1886-1946) je bil prvi, ki je v monografiji Glasoslovje slovenskega cankovskega narečja (1909) ločil tri prekmurske različice: severno - goričko, ki se govori ob zgornji Ledavi in v Porabju, osrednjo - ravensko, ki se govori od Cankove preko Murske Sobote do Filovcev in Kobilja, ter južno - dolinsko, ki je v rabi vzdolž Mure. Na koncu

3 Aktualno stanje ne potrjuje prekmurskih govorcev ob madžarsko-avstrijski meji v Avstriji.

4 Zelo natančno o tem piše Mihaela Koletnik (2008: 10-14).

5 Govor Cankove uvrščamo v ravensko-gorički govor. 
razprave je Pavel pod naslovom »Besedila« (1909: 140-148) v fonetičnem zapisu dodal 15 prekmurskih ljudskih pesmi z oznako kraja; zapisala sta jih z duhovnikom Fidelom Srešem iz Bratoncev. ${ }^{6}$ Po mnenju Vilka Novaka pred temi objavami pri nas še ni bilo tako natančnih fonetičnih zapisov ljudskih pesmi (izjema so zapisi Antona Breznika v Štrekljevi zbirki). Med pesmimi je najbolj znana »Marko skače».

\section{"MARKO SKAČE»}

"Marko skače« je ena najbolj poznanih prekmurskih ljudskih pesmi. Zaradi preproste melodije in verzne strukture jo pojejo že v vrtcih ali v prvi triadi osnovne šole, čeprav po vsebini ni otroška: pripoveduje zgodbo o Marku, ki bi se rad ženil in gre z denarjem v daljno deželo snubit nevesto. Najde jo nekje prek devetih mostov, a mu je njena mati ne da. Zlato perje v mnogih različicah te pesmi bi lahko pomenilo, da je bilo dekle iz bogatejše družine, na kar namigujejo tudi bele roke, ki so jih imela le dekleta, ki so malo delala (Šimonka, 2012: 37). Zapise pesmi najdemo v mnogih pesmaricah, v Štrekljevi zbirki (Slovenske narodne pesmi 3), v Dravčevi zbirki Glasbena folklora Prekmurja in v arhivu Glasbenonarodopisnega inštituta ZRC SAZU. Pesem se je prvotno pela na ozemlju Prekmurja, Porabja in ob hrvaško-slovenski meji. ${ }^{7}$

Nenatančno zapisovanje in poznejše spremembe (popravki) besedil pogosto škodijo prvotni jezikovni podobi ljudskih pesmi in zamegljujejo lokalni značaj besedila. Z novejšimi posnetki in natančno (fonetično) zapisanimi pesmimi lahko rekonstruiramo večino med ljudstvom ohranjenih besedil, npr. pesem »Marko skače« iz Prekmurja in Porabja, ki se je razširila po vsem slovenskem jezikovnem ozemlju in celo na kajkavsko Hrvaško. Pavel je zapisal (1909: 146), da mu je "to čudovito Markovsko ljudsko balado posredoval redovnik Sv. Fidel iz vasi Bratonci. ${ }^{8}$ To je edina opomba k pesmim. Nobena od 15 pesmi nima naslova, povsod pa je zapisano ime kraja (v madžarščini).

\section{Bratonci pri Beltincih (1909)}

1. Màrko skáčä, Màrko skáčä, Po zälẹ́noi tràt! .

Hm hm hm, jàjajai. Po zälẹnoi tràt!.

\section{V ròkaị nòs!̣, v ròkaị nòs! Sàdän žúṭ̣ zlátı̣.}

$H \mathrm{hm}$ hm, jàjajai. Sàdän žútı zlát!̣.

6 Mihael Fidel Sreš (madžarsko Szres Mihály) je bil slovenski teolog, fizik, matematik, kulturnik in profesor; rodil se je leta 1885 v Bratoncih, umrl pa leta 1959 v Košicah na Slovaškem.

7 Leta 1898 je madžarski etnomuzikolog Béla Vikár v prekmurski vasi Tišina med drugimi s fonografom posnel tudi snubitveno pesem »Marko skače«. Pesmi sta mu zapela domačina, 21-letna Anuška Horvat in 45-letni Ferenc Džuban. Posnetke na voščenih valjih hranijo v Etnografskem muzeju v Budimpešti in veljajo za enega prvih posnetkov slovenske ljudske glasbe (Kunej, 2008: 73).

8 Iz madžarščine prevedla avtorica. 
3. Tòu dä nầm! tòu dä nầm Za divòinko daṭ̣.

$\mathrm{Hm} \mathrm{hm} \mathrm{hm,} \mathrm{jàjajai,} \mathrm{Za} \mathrm{divòiko} \mathrm{dat?.}$

4. Píîtä deèitä, piíntä dèi intä Mòiga bráca kòn!.

Hm hm hm, jàjajai, Mòiga bráca kònı.

5. Zdài mo išlı̣, zdài mo išḷ Dàläč po divòiko,

$\mathrm{Hm} \mathrm{hm} \mathrm{hm,} \mathrm{jàjajai,} \mathrm{Dàläč} \mathrm{po} \mathrm{divòiko.}$

6. Prèik dävầtı, prèik däsà̀t!, Sä̀dän sívi mòustov, $H \mathrm{hm} \mathrm{hm,} \mathrm{jàjajai,} \mathrm{Sàdän} \mathrm{sívi} \mathrm{mòustov.}$

7. Tàn jo víḍ̣n, tàn jo víḍ̣n, Fòlašä pomèičää,

$\mathrm{Hm} \mathrm{hm} \mathrm{hm,} \mathrm{jàjajaí,} \mathrm{Fòlašä} \mathrm{pomèičä.}$

8. Zlátı̣n pàrron, zlátı̣n pàron, Z bèillımı rokámı̣, $\mathrm{Hm} \mathrm{hm} \mathrm{hm,} \mathrm{jàjajai,} \mathrm{Z} \mathrm{bèilımı} \mathrm{rokámı.}$

9. N’òi na glávl, nòi na glávı̣, Pántlı̣ı paîntlájo.

$\mathrm{Hm} \mathrm{hm} \mathrm{hm,} \mathrm{jàjajai,} \mathrm{Pántlı̣k} \mathrm{paîntlájo.}$

10. N’òi na pr̀ssai, n’òi na pr̀ssaí, Žvầglıcä žväglájo.

$\mathrm{Hm} \mathrm{hm} \mathrm{hm,} \mathrm{jàjajai,} \mathrm{Žvàglıcä} \mathrm{žväglájo.}$

11. N’òi na ròkai, n’òi na ròkai, Pł̀stanı sväklíjo.

$\mathrm{Hm} \mathrm{hm} \mathrm{hm,} \mathrm{jàjajai,} \mathrm{Pr̀stanı} \mathrm{sväklíjo.}$

12. »Dàjtä mı jo, dàjtä mı jo, Mòja drága màtı̣.

$\mathrm{Hm} \mathrm{hm} \mathrm{hm,} \mathrm{jàjajai,} \mathrm{Mòja} \mathrm{drága} \mathrm{màtı̣.«}$

13. »Nä dàn tı jo, nä dàn tı jo, kùrvä sìn bradát! .

$\mathrm{Hm} \mathrm{hm} \mathrm{hm}$, jàjajai. Kùrvä sìn bradátı̣.

14. Rái jo hòčän (! = ščén), rái jo hòčän F škrìno zaklẹpatı,

$\mathrm{Hm} \mathrm{hm} \mathrm{hm,} \mathrm{jàjajai.} \mathrm{F} \mathrm{škrìno} \mathrm{zakovàt!} .{ }^{9}$

9 Pavel (1909: 30-31) navaja: Marki in Dolinci izgovarjajo nenaglašeni $o$ mnogo bližje $u$-ju kot pravemu $o$-ju, npr. v govoru prijatelja Sv. Fidéla: „Marku szkáče«; »zdaj mu isli«; »tan ju vídim«; »zlátim perun«; "zsveglicze zsvegláju«; »dajte mi ju«; »v skrinyu zaklepati« itn. 
Pavel je o prebivalcih tega območja pisal takole:

"Marki« (màrko, màrkäc) so ljudje v krajih Rakičan, Beltinci (Bòltı̣ncä), Bratonci (Bràtoncä), Odranci, Bistrica, Črenšovci (Črẹnslofcä) in njihovi okolici. Ko sem poizvedoval o izvoru tega ljudskega poimenovanja, so mi povedali, da "záto sä zovẹjo màrk!̣, ár jä sàkšäm! drügom! màrko, màrkäc imẹe ['zato se imenujejo marki, ker je vsakemu drugemu ime Marko, Markec', op. T. J.]. Najbrž je tu nastala tudi lepa balada o Marku [Marko skače, op. T. J.]. Tukajšnji prebivalci zelo radi pojejo in ravno tu je slišati iz ljudskih ust največ pesmi, romanc in balad..$^{10}$ (Pavel, 1909: 4-5)

Pavel je v Glasoslovju predstavil vse glasoslovne značilnosti tega prekmurskega narečja. Naj jih naštejemo zgolj nekaj:

- zaokroženje kratkega in nenaglašenega $a$ je značilno tako za ravensko kot goričko varianto prekmurščine, npr. fànț̣,$^{11}$ màt!̣;

- dolgi a je nezaokrožen, sprednji oz. rahlo e-jevski (à), npr. jágrı̣cäk, sábla;

- za dolgi e imajo dvoglasnik oz. diftong ei: mlèiko 'mleko', lèiko 'lahko';

- za dolgi o pa diftong oun: mòust;

- v panonski narečni skupini se je dolgi $u$ pomaknil v izgovoru naprej (ü);

- značilno je tudi, da -m v izglasju prehaja $\mathrm{v}-n$, npr. sầdän 'sedem'.

Prekmurska različica v fonetični pisavi (Pavel, 1909) kaže naslednje narečne značilnosti:

\section{1. v glasoslovju:}

- samoglasnik e se izgovarja kot dvoglasnik ei (prèik, pomèičä, z bèillımı);

- samoglasnik o se izgovarja kot dvoglasnik ou (mòust, tòu);

- končni soglasnik - $h(x)$ se izgovarja kot -j (na pìsaí, na ròkai);

- končni soglasnik - $m$ se izgovarja kot -n (sàdän, tàn, vídı̣n, zlátın pầron, nä dàn, hòcäa); ;2

- primer jotacije oz. prehoda $j \mathrm{v} d$ '[dj]: dèi

- mehki ń je ohranjen (škrińa);

- zveneči soglasnik $v$ se v položaju pred nezvenečim nezvočniki izgovarja nezveneče, tj. kot $f(f$ škrińo);

- za prekmursko narečje je značilen tudi zlogotvorni zvočnik $r$ (na pìssai 'na prsih', pìsstanı);

2. na oblikoslovni ravnini izstopajo nekatere oblike:

- -i pri samostalnikih v dajalniku in mestniku ednine: po zälénoi (M ed., knj.po zeleni);

10 Pavlova zvrstna opredelitev je napačna, ker pesem ni balada.

11 V skladu z nacionalno fonetično transkripcijo danes kratki zaokroženi à zapisujemo z $\stackrel{a}{ }$, npr. $b^{\prime}$ råt (Jakop, 2017). Sodobno narečno gradivo (zapisano z novo transkripcijo) avtorica zbira na terenu od leta 2006.

12 Za vse panonske govore je namreč značilno, da $-m$ v izglasju prehaja $\mathrm{v}-n$.

13 Govor vasi Bratonci ima danes na tem mestu glas $j$. 
- raba tožilnika namesto rodilnika zanikanja: nä dàn tı jo (R > T) (knj. ne dam ti je);

- pomožni glagol prihodnika je mo (< bomo) (zdài mo išll 'zdaj bomo šli');

- ponavljalni glagol pometati ima sedanjiško obliko pomeče (pomèčä), ki je nastala po jotaciji; 3. v besedju: $:^{14}$

- žút 'rumen, zlat' < žolt < *žbltb 'rumen';

- divòika 'deklica' Ł *děva 'mlada, vendar že odrasla mlada ženska';

- folaš 'hodnik' < madž. folyosó; "folašä pomèčä" 'pometa hodnik';

- pántlık '(pisan) trak, trakec' < madž. pántlika 'trak, trakec' < nem. Band'trak' (Novak, 1996: 94: s pántlikami so si okinčali kranšćáke ['s trakovi so si okrasili klobuke’, op. T. J.];

- žvầglıcä žväglájo $;^{15}$ žveglati 'piskati', žvegla 'vrsta piščali, piščalka' (srvnem. svëgele 'vrsta piščali', iz česar se je razvilo današnje nem. Schwegel v enakem pomenu (StriedterTemps, 1963: 256).

Naslednja prekmurska varianta pesmi je bila posneta leta 1955 v Beltincih. Josip Dravec je pojasnil, da je to »ena najbolj znanih pesmi v Prekmurju [...]. Slišimo jo v vsaki vasi, zlasti na Dólinskem, kjer jo imajo v šali za svojo himno« (Dravec, 1957: 337). Dolince drugi Prekmurci imenujejo tudi Marki in pravijo, da bi jih naj tako imenovali ravno zaradi te pesmi. Tudi Zmaga Kumer (1971: 102) je zapisala, da imajo na Dolinskem pesem »Marko skače» "za nekakšno svojo himno" in da jih sosedje prav zaradi nje imenujejo Marki. Različica iz Beltincev, ki jo je objavila tudi Zmaga Kumer (n. d.: 103-104), je zapisana na folklorističen način (torej nefonetično), zato ni razvidna natančna kvaliteta samoglasnikov.

1. Marko skače po zelenoj trati.

2. V rokaj nosi seden žuti zlati.

3. Tou de njemi za devojko dati.

4. Pijte, jejte, mojga bratca konji!

5. Zdaj mo išli daleč po devojko.

6. Preik deveti, preik deseti mostov.

7. Tam jo vidim, folaše pomeiče.

8. Zlatim perom, z belimi rokami.

9. Njoj na glavi pantliki pletajo.

10. Njoj na prsaj žviglice žveglajo.

11. Njoj na rokaj prstani svetlijo.

12. Dajte mi jo, draga moja mati!

13. Ne dam ti jo, kurve sin bradati!

14 Poleg besed slovanskega izvora so v tem narečju izposojenke, prevzete v različnih obdobjih. Največ je germanizmov (prevzeti zlasti iz južne bavarske nemščine v narečno slovenščino) in hungarizmi oz. madžarizmi.

15 Tjaša Šimonka (2012: 37) meni, da so to nekakšni okraski na obleki, ki ob premikanju oddajajo določene zvoke. 
14. Raj jo hočem $v$ škrinjo zaklepati!

15. Naj jo jejo miši no podgani!

16. Naj jo jejo kebri no stenice! $!^{16}$

\section{Glasoslovje:}

- dvoglasnik ei je ohranjen (preik, z beilimi, pomeiče);

- kjer jepri Pavlu dvoglasnik oz. diftong ou, je v tem zapisu že monoftong oz. enoglasnik (mostov);

- končni soglasnik $h(x)$ se izgovarja kot $j$ ( $v$ rokaj, na prsaj);

- končni soglasnik $m$ je le redko zapisan z $n$ (seden toda tam, vidim, zlatim perom, hočem, ne dam);

- namesto nezvenečega predloga pred nezvenečimi soglasniki, ki ga je Pavel zapisal s $f$, je v tem besedilu že poknjiženi predlog $v$ ( $\underline{s}$ škinjo).

Pri oblikoslovju in besedju (leksiki) razlik ni. Različica iz Beltincev ima še dodatna verza: ko mati pove, da hčer raje, kakor da jo odda Marku, zaklene v skrinjo, še doda, naj jo jejo miši in podgani (m. sp. mn.) ter kebri in stenice.

Dravec (1957: 161-162) je v svoji zbirki podal dva zapisa pesmi »Marko skače«: prvi iz leta 1949 je iz Beltincev, drugi iz leta 1952 pa iz Žižkov (na Dolinskem). V prvi različici je zanimivo olepševanje (pri 7. in 8. kitici): "Dajte mi jo, moja zlata mati!" I - Ne dam ti je, star si i bradati [...] Druga varianta je daljša in se v prvem delu ne razlikuje od prve, na novo pa dodaja naslednje verze (n. d.: 162):

Sneha nam je na senje odišla,

Tan je küpla seden lakti $v$ ritko.

Nesli boudo sen dvanajstin švéljam,

Šivale do lače no robače. ${ }^{17}$

Najstarejši zapis pesmi »Marko skače« je iz Štrekljeve zbirke Slovenske narodne pesmi 3 (št. 5443). Zanj je Štrekelj napisal, da je iz Cerovca. Ker je pesem (prvi) zapisal Stanko Vraz v 30. letih 19. stoletja (Narodne pesni ilirske..., 1839), je verjetno mišljen Cerovec v občini Ormož. Vraz je kot zapisovalca navedel Matijo Preloga in zato je Zmaga Kumer (1971: 102) menila, da naj bi bil zapis iz Prelogovega kraja, torej iz okolice Radgone ali pa iz Hrastja (pri Radencih) in ne iz Cerovca, kakor je napisal Štrekelj. Pod pesmijo je še komentar, $\mathrm{v}$ katerem je omenjeno, da je bila pesem zapisana $\mathrm{v}$ drugi različici, in sicer so omenjene

16 Pesem je tu zapisana brez ponavljanj.

17 Te zadnje štiri vrstice se po vsebini odmikajo od drugih različic, vendar jih je pevka pela na enako melodijo kot "Marko skače» (Dravec, 1957: 338). Vsebujejo značilno panonsko besedje, npr. švelje 'šivilje' bodo šivale lače no robače 'hlače in srajce'. 
besede, ki se razlikujejo v zapisu, npr. žutih (nam. žoltih) in divojko (nam. ženico): Marko skače - po zelenoj travi, I v roki nosi-sedem žoltih zlati:/ To de njemi - za ženico dati. [...]

"SONCE GRE ZA GORO»

\section{Bratonci (1909)}

1. Sùncä grẹ za goròu,

Mòčno jä žàlostno.

Lèiko jä žàlostno,

Ár dä nad vòisko šlò.

2. Fàntı̣č nad vòisko gré,

Sáblı̣co má krä sé,

Sáblä bliskà̃cäjo,

Fàntı̣ träpàcääjo.

3. Krùgla že zabrní.

Fànțč na stràn (!) läží.

Maríja grẹ́ krầnäga,

Fàntı̣ca gòr bidí.

4. »Stàn! gòr fàntı̣c mòì!

Pòidva za Jẹzušon."

»Nầmrän gòr stànot!̣:

Krùglo prẹ sr̆c̣ màn.

\section{Lèipä jä là̀lḷa}

Ròuža Maríjı̣na.

\section{Glasoslovje:}

- samoglasnik e se izgovarja kot dvoglasnik ei (lèipä, lèiko 'lahko');

- samoglasnik o se izgovarja kot dvoglasnik ou (ròuzza, za goròn);

- mehki $l$ je sredi besede že otrdel v $l$ (sáblä 'sablje’).

\section{Oblikoslovje:}

Za panonski prostor so značilne posebne oblike nedoločnikov in deležnikov na -l glagolov na -noti -nem (v knj. sln. -(n)iti -(n)em), v pesmi npr. gòr stànot? 'vstati' (Pavel, 1909 še: gùtnot!̣ 'požreti, srkniti', pầinot!̣ 'pahniti', spàdnoṭ 'pasti', sünoṭ! 'suniti', zàčnot!̣, zakùnot! 'prekleti, zakleti', zầinot! 'zehniti' (po Jakop, 2017)). Značilna je tudi zanikana oblika nä̀mrän 'ne morem'. 
Besedje: krùgla 'krogla' (Pavel, 1909: „krùgla prilätèila, Sìcä m! zadèilla«, "krùgla, mà̀ tàn vmorí (iz ljudskih pesmi)); predlog krä 'ob' (krä sẹ 'ob sebi', krä̀äga 'ob njem'), ár 'ker'; prevzem iz knjižne slovenščine: grẹ za prekmursko idä. ${ }^{18}$

V zbirki Pesem slovenske dežele (Kumer, 1975: 473) je objavljena različica iz Porabja (Gornji Senik) iz leta 1970 z naslovom »Marija pride na bojišče po ranjenca«:

1. Sonce gre zá gorou,
móčno je žalosno,
lejko je žalosno,
ar de med vojsko šow,
ar de med vojsko šow.

2. Fántič gre méd vojsko ${ }^{u}$, brüsi si sablico.

3. Sable bliskéčejo, fanti tarpéčejo.

4. Krugla mi zábrni, fant paj na stran leži.
5. Marija tam mimo gre, zove ga za ime:

6. Stani gor, fantič moj, hodva za Jezušom.

7. Nemrem gor vstánuti, kruglo pri src imam.

\section{Le pa je lelija} ro ${ }^{u z ̌ a ~ M a r i j i n a . ~}$

9. Ki de to pesem ču, on de se žálostiw.

\section{Glasoslovje:}

- samoglasnik e se izgovarja kot dvoglasnik ei (lejko 'lahko', le $\left.e^{i} a\right)$;

- samoglasnik o se izgovarja kot dvoglasnik ou (roǔza, zá goro ${ }^{u}$, méd vojskou $)$;

- mehki $l$ je sredi besede že otrdel v $l$ (sable 'sablje').

\section{Oblikoslovje:}

Za panonski prostor so značilne posebne oblike nedoločnikov in deležnikov na $-l$ glagolov na -noti -nem (v knj. sln. -(n)iti-(n)em), v pesmi npr. gor vstánuti 'vstati'. Tipična je tudi zanikana oblika nemrem 'ne morem'.

Besedje: krugla 'krogla'; ar 'ker', zove 'kliče'.

\section{»PO LOUGI LEIČE»}

Pesem »Po lougi leiče ${ }^{19}$ so peli v raznih delih Prekmurja, se je pa iz kraja v kraj spreminjala. $\mathrm{V}$ pesmi žolna prosi mladega lovca, naj je ne ustreli, ter mu svetuje, kakšno ženo naj si izbere.

18 Za glagol iti se v prekmurskem narečju namesto korena gre- uporablja ide- (npr. ideva), ki izhaja iz nadomestne nedoločniške osnove *id- (Jakop, 2007: 604), npr. 'iden 'grem'.

19 To je živalska pripovedna pesem, ki jo je Štrekelj (Slovenske narodne pesmi: 1. zvezek) uvrstil v tip "Ptičev svet za dobro ženitev« (različica 926 je npr. iz Cerovca). 


\section{Bratonci (1909)}

1. Po lòug! lèičä, po lòng! lèičäa

Ädnä žúta žùnı̣ca.

Lẹdràilaịlòilala!

Ädnä žúta žùnı̣ca.

2. Za ńòuv m! (h)òdı, za ńòuv m! (h)òd!

Ädän mládı̣ jágrı̣čäk.

Lẹdràilaịlòilala!

Ädän mlád! jágrı̣čäk:

3. »Nä strèill (ali strèilaín) da mä, nä strèill da mä,

Tí mlád! jágrı̣čäk!

4. Jầs tä podučìn, jầs tä podučìn,

Kàk sä mòräš ozzänı̣t (! = ožänìt! ).

5. Nä zầm

Ädnä stárä bàbä čẹ́r.

6. Ár stára bàba, ár stára bàba,

Úna pùna krèigańa.

7. Nä zà̀m

Ädno mládo vdòvịco.

8. Ár mláda vdòva, ár mláda vdòva,

Úna pùna žàlostı.

9. Li vzầm

Ädno mládo dẹklı̣co.

10. Ár mláda dẹkkla, ár mláda dệkla,

Úna pùna väsäld'á.

Lẹdràilaịlòilala!

Úna pùna väsäld'á.

\section{Glasoslovje:}

- samoglasnik e se izgovarja kot dvoglasnik ei (lèiciü, strèill , krèigańa);

- samoglasnik o se izgovarja kot dvoglasnik ou (lòugl, za ńòuv 'za njo'); 
- stalno dolgi in staroakutirani -to-> -ou- > u (pùna 'polna', žùnı̣ca 'žolnica');

- primer jotacije oz. prehoda $j \mathrm{v} d^{\prime}[d j]$ (väsäldẹ ${ }^{20}$ 'veselje' < stcsl. veselb 'vesel').

\section{Oblikoslovje:}

- ponavljalni glagol letati ima sedanjiško obliko leče (lẹ̀ ǐc̆ä), ki je nastala po jotaciji (kot npr. metati mečem < *met-je-m).

Besedje: lòug 'gozd', žùna, žùnıca 'žolna'; žútı, -a, -o 'rumen'; lèìčä 'leta', nä strèilı̣ (ali strèilaîn) 'ne ustreli', nä zầm 'ne vzemi' ...

Dravec (1957: 209-210) je različico iz Kroga (Prekmurje) zapisal leta 1950: ${ }^{21}$

Po lougi leiče, po lougi leiče,

edna žuta žunica.

(Ledrajla lijala, ledrajla lijala),

edna žuta žunica.

Za njouf mi hodi eden mladi jágerček.

Na rami nosi edno pükšo nacèrano.

Ti pai méne doi ne strêlaj,

Jas ti nekaj povédla bom:

as ti nekaj povedla bom:

»Stare babe si ne jemli,

ona puna je kreganja.

Mlade vdove si ne jemli,

Ona puna je žalosti.

Mlado dekle si le vzemi,

Ona puna je vèseljá.»

\section{Glasoslovje:}

- dvoglasnik ei ni dosledno zapisan (leiče, toda strêlaj in kreganja);

- dvoglasnik ou je dosledno zapisan (lougi, za njouf'za njo');

- prehod -ol->u (žuta žunica, puna);

- jotacije oz. prehoda $j \mathrm{v} d$ 'ni (vèseljá).

\section{Oblikoslovje:}

- ponavljalni glagol letati ima sedanjiško obliko leče (lèi čă), ki je nastala po jotaciji.

Besedje: loug 'gozd', žunica 'žolna'; žuta 'rumena'; leiče 'leta' ...

20 Govor vasi Bratonci ima danes na tem mestu glas $j$.

21 Drugi zapis 1952 iz Žižkov (Dravec, 1957: 210) je skoraj identičen, le krajši. 


\section{SKLEP}

V prispevku osvetljujemo narečno podobo izbranih prekmurskih ljudskih pesmi. Njihov jezik navadno ni pravo narečje, je vmesna stopnja med narečjem in knjižnim jezikom. Narečnosti se najbolj približajo zapisi v fonetični pisavi. V članku smo analizirali nekaj prekmurskih narečnih pesmi, objavljenih leta 1909 v glasoslovni razpravi Avgusta Pavla, in jih primerjali z istimi pesmimi v nadnarečni podobi. Med obravnavanimi pesmimi je najbolj poznana "Marko skače«, ki se je iz kraja v kraj le rahlo jezikovno spreminjala in se je vse do danes ohranila s skoraj nespremenjenim besedilom; vsebinsko se torej ni spreminjala, se je pa prevrstila iz snubitvene v otroško pesem.

Kot so etnomuzikologi pozorni na spremembe v glasbi ljudskih pesmi, folkloristi na melodične in hkrati besedne oz. jezikovne spremembe, smo dialektologi pozorni zgolj na jezik oz. narečje ter izgovor besedil ljudskih pesmi, ki jih natančno zapisujemo s posebno fonetično pisavo. Besedila prekmurskih pesmi, zapisanih pred letom 1909, so dragocen in verodostojen relikt časa pred pospešenim zapisovanjem prekmurskega pesemskega izročila (po 1. svetovni vojni) ter dober vir za nadaljnje analize in primerjave s poznejšimi zapisi. Avtorica bo v prihodnosti transkribirala, narečjeslovno pregledala in analizirala še preostale pesmi, skrite $\mathrm{v}$ madžarsko pisanem in v Budimpešti tiskanem dialektološkem delu Prekmurca Pavla, ki ga do danes folkloristi in etnomuzikologi še niso obravnavali, narečjeslovcu pa nudi vpogled v (ne)spreminjanje tega narečja.

\section{REFERENCE}

Dravec, Josip. 1957. Glasbena folklora Prekmurja: Pesmi. Ljubljana: SAZU.

Golež Kaučič, Marjetka. 2003. Ljudsko in umetno - dva obraza ustvarjalnosti. Ljubljana: Založba ZRC, ZRC SAZU.

Golež Kaučič, Marjetka. 2018. Slovenska ljudska balada. Ljubljana: Založba ZRC, ZRC SAZU.

Jakop, Tjaša. 2006. (Nad)narečna podoba slovenske pripovedne pesmi. Jezikoslovnizapiski 12:51-69. DOI: https://doi.org/10.3986/jz.v12i1.2534.

Jakop, Tjaša. 2007. Razlikovanje glagolskih oblik po spolu v sedanjiku dvojine greve. Slavistična revija 55 (4): [601]-613. https://srl.si/sql_pdf/SRL_2007_4_1.pdf.

Jakop, Tjaša. 2017. Govor Cankove od Pavlovega Glasoslovja (1909) dalje. V Avgust Pavel med Slovenci, Madžari in Avstrijci = August Pavel among the Slovenians, Hungarians and Austrians, ur. Marko Jesenšek, 53-64. Maribor: Univerzitetna založba Univerze v Mariboru.

Koletnik, Mihaela. 2008. Narečna podoba Prekmurja. V Panonsko lončarsko in kmetijsko izrazje ter druge dialektološke razprave, ur. Zinka Zorko, 9-16. Maribor: Mednarodna založba Oddelka za slovanske jezike in književnosti, Filozofska fakulteta.

Kumer, Zmaga. 1971. Marko skače po zelenoj trati. Muzikološki zbornik 7: 102-113. http://www.dlib. si/?URN=URN:NBN:SI:doc-HR4QGGIA.

Kumer, Zmaga. 1975. Pesem slovenske dežele. Maribor: Založba Obzorja. 
Kumer, Zmaga. 2002. Slovenska ljudska pesem. Ljubljana: Slovenska matica.

Kunej, Drago. 2008. Fonografje dospel!: Prvi zvočni zapisi slovenske ljudske glasbe. Ljubljana: Založba ZRC, ZRC SAZU.

Logar, Tine. 1975. Slovenska narečja. Ljubljana: Mladinska knjiga.

Merhar, Boris. 1961. Slovenske ljudske pesmi. Ljubljana: Mladinska knjiga.

Novak, Franc. 1996. Slovar beltinskega prekmurskega govora. Murska Sobota: Pomurska založba.

Novak, Vilko. 1936. Izbor prekmurske književnosti. Celje: Družba sv. Mohorja v Celju.

Pavel, Avgust. 1909. A vashidegkútiszlovén nyelvjárás hangtana. Budimpešta: A Magyar Tudományos Akadémia.

Snoj, Marko. 2015. Slovenski etimološki slovar. https://fran.si/.

Stanonik, Marija. 2008. Slovenska slovstvena folklora in slovstvena folkloristika. V Slovenski folklor $i$ folkloristika na razmedi dva milenijuma, ur. Ljubinko Radenković, 155-183. Beograd: Balkanološki institut SANU.

Striedter-Temps, Hildegard. 1963. Deutsche Lehnworter im Slovenischen. Berlin, Wiesbaden: OsteuropaInstitut, Otto Harrassowitz.

Šimonka, Tjaša. 2012. Prekmursko ljudsko izročilo skozi šest pesmi za ženski zbor. Diplomsko delo. Maribor: Univerza v Ljubljani, Pedagoška fakulteta. https://dk.um.si/Dokument.php?id=51605.

Štrekelj, Karel. 1904-1907. Slovenske narodne pesmi: 3. zvezek. Ljubljana: Slovenska matica.

Terseglav, Marko. 2004. Folkloristika in literarna veda ali eseji o ločitvi. Traditiones 33 (2): 17-45. DOI: https:// doi.org/10.3986/Traditio2004330201.

Zorko, Zinka. 1994. Panonska narečja. V Enciklopedija Slovenije 8, ur. Marjan Javornik idr., 232-233. Ljubljana: Mladinska knjiga.

\section{SLOVENIAN FOLK SONGS IN PREKMURJE DIALECT}

In this article we shed light on the dialectal picture of Slovenian folk songs. The language of folk songs is usually not a proper dialect, but an intermediate stage between dialect and written language (in most cases it is a supra-dialect). Folk songs in phonetic writing come closest to the original dialect image of a folk song. In this article we will analyse some dialect folk songs from the Prekmurje region in the phonetic transcription recorded by a linguist August Pavel (published in 1909); these will later be compared with the same folk songs in supra-dialectal form.

Just as ethnomusicologists pay attention to changes in the music offolk songs, dialectologists pay attention to the language or dialect and pronunciation of song's lyrics: Through space and time both the melodies and the language of the lyrics change. If in the $20^{\text {th }}$ century there was a tendency to standardise Slovene folk songs, after independence their regionalism began, reviving the dialect. Today, originality can be verified with the help of old recordings or precisely written lyrics (in phonetic script). The folk singers and musicians and other performers of folk music, 


\section{TJAŠA JAKOP}

who show the diversity of the Slovene language and its regional and dialectal peculiarities in the songs, can preserve or change the folk song the most.

Dr. Tjaša Jakop, ZRC SAZU, Inštitut za slovenski jezik Frana Ramovša, tjasa.jakop@zrc-sazu.si 